\title{
RURAL DEVELOPMENT ACCORDING TO REGIONAL PLANNING STRATEGIES CASE STUDY (EGYPT AND SAUDI ARABIA)
}

\author{
Jozsef Kaposzta, Henrietta Nagy, Samir Zaien, Gabriella Horvath-Csikos, Hanna Andrea Solyomfi \\ Szent Istvan University, Hungary \\ kaposzta.jozsef@gtk.szie.hu,nagy.henrietta@gtk.szie.hu, zaien.samir@gtk.szie.hu, \\ horvath.csikos.Gabriella@gtk.szie.hu, solyomfi.andrea.hanna@phd.uni-szie.hu
}

\begin{abstract}
The rural territories of the third world are important demographic factors, which indirectly contribute to the social balance as the countryside means the strategic depth of the society, because it is responsible for food-safety and for securing the unqualified labour. Unfortunately, the majority of the developing countries could not reach that balance as they ignored rural economy, which is reflected in agriculture and animal husbandry. Investment in these branches was under the standard and what they reached was developed in the form of suggestions suppressing social demands and was without promoting the well-being and developmental projects of the rural population. However, some countries realized the importance of this role and elaborated developmental strategies for improvement, thus they reached the developmental balance between the poles of urban and rural societies and provided fertile field for participation of the rural population and for the social and economic development as well. Recently the interest in the developmental strategy towards the Egyptian and Saudi-Arabian territories has increased. With elimination of the developmental differences between the communities of rural and urban population and with increasing the social and economic level of the countryside, the aim was to reach the social and economic balance soon in order to let the countryside participate effectively in the developmental processes.
\end{abstract}

Keywords: developing countries, rural development, Egypt, Saudi Arabia.

\section{Introduction}

The concept of development is: „elaboration of forecasting strategies based on scientific principles, the aim of which is to reach all life goals focusing separately or jointly on social, economic and environmental aspects" [1].

Rural development is an essential part of the general national development as it is not possible to support a region, where certain fields are not yet developed. These fields primarily have to be helped to reach a balanced development and later it has to be implemented by applying regional development within the strategies of the future national plan.

The rural territories of the third world are important demographic factors, which indirectly contribute to the social balance as the countryside means the strategic depth of the society, because it is responsible for food-safety and for securing unqualified labour.

The urgent establishment of modern developmental plans was required after the launch of urban development in certain developing countries and because of the acceptance of the legal requirement concerning regional planning. These plans should reflect their positive impacts on economic, service providing and social fields of different regions. Furthermore, they should create balance between the regions according to the available possibilities.

The aim of the present study is to revel the real causes of the problems occurring in the rural territories of developing countries (both from the aspect of services and urbanization) within the regional frames in order to contribute to proper solution of the problem.

The main issues of the study:

- strategies for regional planning and integrated rural development are missing in the developing countries;

- there is a significant increase in the number of the rural population and in their migration to cities as they are not satisfied with the services offered in the countryside;

- the standard of living is lower in the countryside than in the cities (as regards economy, employment and services);

- rural areas have been neglected in the previous developmental strategies. 
The aims of the study:

- to revel the real causes of the problems occurring in the rural territories of developing countries (both from the aspect of services and urbanization) within the regional frames in order to contribute to proper solution of the problem;

- to establish the bases for rural development in developing countries and to reach a real regional balance between the region and countryside.

The importance of the study: the introduction of rural developmental strategies through research samples can serve as the basis for studying other rural territories of developing countries, thus activating the role of rural development in order to reach a regional balance between the city and the countryside, which might contribute to reach economic, demographic and political balance in these countries.

\section{Rural development in the framework of regional planning}

\section{The concept of rural development}

Rural development is determined as the sets of such developmental measures, the aim of which is to reach the wellbeing of the rural population by implementing developmental projects, where more effective measures complement each other, such as investing into development of the infrastructure, increasing the living standard, stimulating and supporting education and improving the living conditions of rural people [2].

Others determine rural development as a continuous change, which was planned for the overall improvement of life concerning different aspects of life, mainly combining the democratic approach of rural people and governmental support in order to reach integration of the developing territories and integration of the developing society with the national society [3].

\section{Regional planning and rural development}

Regional planning provides the connection between the national and local plans. It means phrasing of the proper methods based on the framework of the proper developmental projects and the advanced condition of the rural problems and territories. It includes land-use planning and implementation of improved rural developmental projects in order to ensure complete alignment of plans between the urban and rural territories. Based on the experiences in the field of rural development, integrated regional planning is considered to be the best method for planning rural development.

\section{Features and functions of regional planning}

The importance of regional planning can be found in its features and functions, therefore, these features and functions have to be defined in order to realize the planning types focusing on spatial dimensions, which serve as the basis for all development activities.

Main features and functions of regional planning:

Regional planning serves as a tool for coordination between different regions and between different branches, organisations, bodies or developmental projects.

Regional planning limits regional differences.

1. Regional planning fights all kinds of confusion. It focuses on poverty, unemployment and on the problems of migrating population.

2. Regional planning might achieve participation of citizens in order to overcome and solve different problems.

3. Regional planning gives a realistic picture of the natural potentials and of the human resources of certain regions and also of the way how these resources are used effectively and how they are applied in a positive way in order to reach the spatial balance within the region and between other regions. 


\section{Regional planning policy and rural development}

1. Controlling local resources: success of rural development depends largely on the quantity of natural resources and on the available human resources, and on the method of their exploitation. The greater the investment to be implemented is from national resources, the closer the plan is to reality and it guarantees more success.

2. The successful rural developmental projects already meet the requirements of the rural society.

3. In order to have favourable circumstances for rural development, rural people have to feel that they are treated equally with urban merchants, industrialists and employees as rural communities were always the last priorities of national plans.

4. Developing national plans, which create balance between rural development and urban development in order to establish a regional balance decreasing the differences between villages and cities, might serve as a tool to control overpopulation [4].

\section{Objectives of regional planning in connection with the objectives of rural development}

Connecting the national schedule of the local rural developmental projects in order to phrase the economic and social policy of the national general plan to meet the requirements of the rural developmental process.

Promotion of rural economic development largely depends on the different services offered for the employees in different rural developmental projects.

Compensating the decrease in productivity of agriculture (substituting, replacement) by diversification of employment opportunities of light industry and local craft in rural territories.

Developing proper awareness in the circle of farmers, providing guidance and support for them in order to motivate them for self-supply, moreover, providing them education services, which are in accordance with the cultural level, customs and traditions of the rural children.

The well-operating rural developmental models justify that any of the ideas can be successful only with cooperation of the locals. It is necessary to realize the needs of the community and to have willingness to make efforts to reach the common goal. The communal cooperation favours validation of equal treatment and development of social solidarity.

Preparation of rural developmental programs aiming at examining the available resources and opportunities within the region expansively.

Preparation of regional studies connecting studying of rural communities from the same region.

Village planning systems have to be ratified in order to prevent the unplanned spread of villages.

Better alignment of rural developmental projects in connection with land-use.

Application of the proper technology for rational and effective use of natural resources.

Ensuring training of the suitable individuals in the regional planning technology by establishing the necessary educational institutions. This training is necessary for integration and preparing for the methods of integration from all dimensions of planning (from economic, social and administrative aspects and also from the connections between each dimension).

\section{Experiences of rural development in the developing countries from the aspect of regional planning}

\section{Case study from Egypt}

The Egyptian village is the corner stone of the Egyptian society and cultural centre; therefore, attention had to be paid to the Egyptian countryside because of their problems and disadvantages (problem of the services, lack of employment opportunities, rural-urban migration, and lack of public utilities, water and electricity).

Egypt has made several attempts in rural development, where the first national program for development was accepted by the General Authority for Rural Development in Egypt in 1994. The aim of the program - called "Shuruq" - was to prepare the general strategic plans for Egyptian villages. The first phase of the project was finished in 2002 and altogether 522 villages' developmental plans were prepared in the governments of Delta and Wadi. 
The developmental strategy in Egypt was focusing on establishment of integrated rural units, which started with the establishment of 250 combined units. This consolidated unit provided economic, social, health and educational services in a coordinated way. The unit serves one or more villages with the population of 15000 .

\section{Experiences with regard to development of the villages in Assiut County}

During centuries, Egyptian villages were established in any directions at random, without planning. These rural communities were suffering from economic and social problems for a long time, although rural communities represent the major part (more than half) of the population of Egypt. Some studies examining the situation of Egyptian villages in general and especially the condition of the three villages (Mankabad, El Matta, El Nikhila) of Assiut County that can be found in Fig. 1 reveal that the majority of Egyptian villages were not at all planned in practice. Despite the fact that there were studies in connection with the field of rural development in Egypt, unfortunately, these plans were not crystallised, consequently the Egyptian villages spread to agricultural territories unintentionally [5].

Strengths, weaknesses and also the developmental strategies and suggestions for the villages in Assiut County are summarized in Table 1.

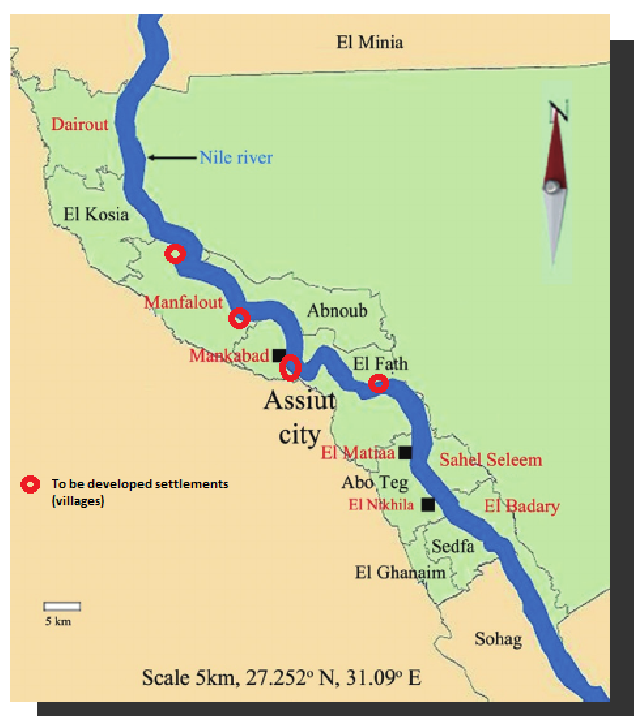

Fig. 1. Map of Assiut Governorate [6]

Strengths, weaknesses and also the developmental strategies and suggestions for the villages in Assiut County

\begin{tabular}{|c|c|c|c|}
\hline $\begin{array}{l}\text { Name } \\
\text { of the } \\
\text { village }\end{array}$ & Strengths & Weaknesses & $\begin{array}{c}\text { Developmental strategies } \\
\text { and suggestions }\end{array}$ \\
\hline $\begin{array}{l}\text { Villages } \\
\text { in } \\
\text { general }\end{array}$ & $\begin{array}{l}+\quad \begin{array}{l}\text { Fertile agricultural soil } \\
\text { and permanent sources } \\
\text { of water }\end{array} \\
+\quad \begin{array}{l}\text { They lie by the } \\
\text { branches of the Nile }\end{array} \\
+\quad \begin{array}{l}\text { Most of the villages are } \\
\text { reached by railroad and } \\
\text { either by local or } \\
\text { regional main roads }\end{array}\end{array}$ & $\begin{array}{l}\text { Population in the } \\
\text { villages largely depends } \\
\text { on cities as regards their } \\
\text { everyday consumption, } \\
\text { and it means that the } \\
\text { village turned to a } \\
\text { consuming unit from } \\
\text { another production unit, } \\
\text { which secured the main } \\
\text { supply of the population } \\
\text { in the cities. }\end{array}$ & $\begin{array}{ll}\text { Usage of non- } \\
\text { agricultural territories in } \\
\text { order to develop and } \\
\text { improve services and } \\
\text { agricultural territories. } \\
\text { - } & \text { Ensuring civilized } \\
\text { urban environment. } \\
\text { - Increasing the } \\
\text { effectiveness of services } \\
\text { and infrastructure } \\
\text { Developing the } \\
\text { supplementary road } \\
\text { networks }\end{array}$ \\
\hline
\end{tabular}


Table 1 (continued)

\begin{tabular}{|c|c|c|c|}
\hline $\begin{array}{l}\text { Name } \\
\text { of the } \\
\text { village }\end{array}$ & Strengths & Weaknesses & $\begin{array}{c}\text { Developmental strategies } \\
\text { and suggestions }\end{array}$ \\
\hline $\begin{array}{l}\text { Villages } \\
\text { in } \\
\text { general }\end{array}$ & 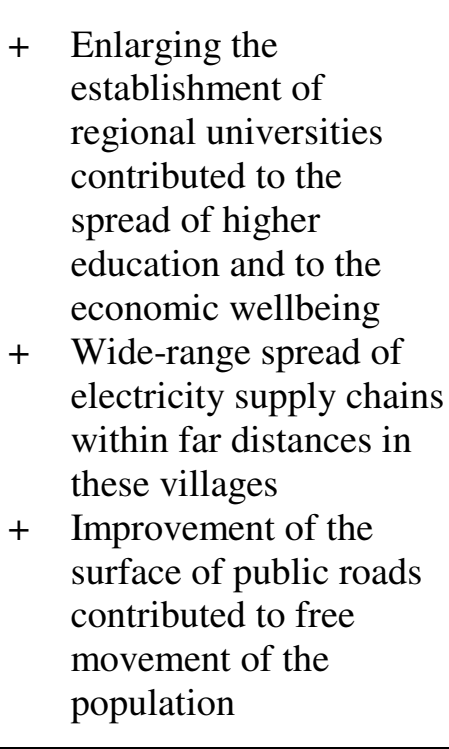 & 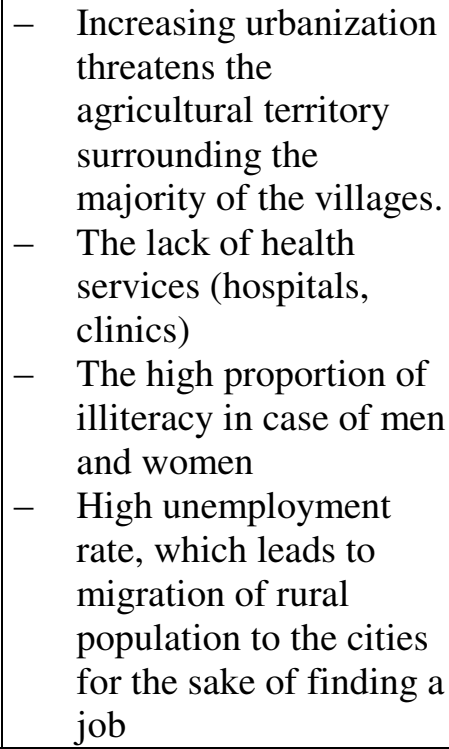 & $\begin{array}{l}\text { Optimal exploitation of } \\
\text { natural facilities of the } \\
\text { village and connecting } \\
\text { it to the environment } \\
\text { and to the urban centre } \\
\text { - Preparing general plans } \\
\text { of the village based on } \\
\text { the approved } \\
\text { construction areas. } \\
\text { These plans guide the } \\
\text { development progresses } \\
\text { within the framework of } \\
\text { regional planning. }\end{array}$ \\
\hline
\end{tabular}

\section{Case study from Saudi-Arabia}

Saudi-Arabia paid particular attention to improve the population standard of living by having comprehensive economic and social developmental programs for the rural territories. Saud-Arabia gained a lot of experience in the field of rural development and regional planning, including the examination of the villages in Asir region, especially studying the village of Al Obaidiyah.

The developmental plans of Saudi-Arabia verified that the rural developmental strategy was part of the comprehensive national developmental strategy, by the help of which the main developmental goals could be implemented in the Kingdom. Rural development and improvement of the population standard of living ensure integration and balance of the national developmental processes [7].

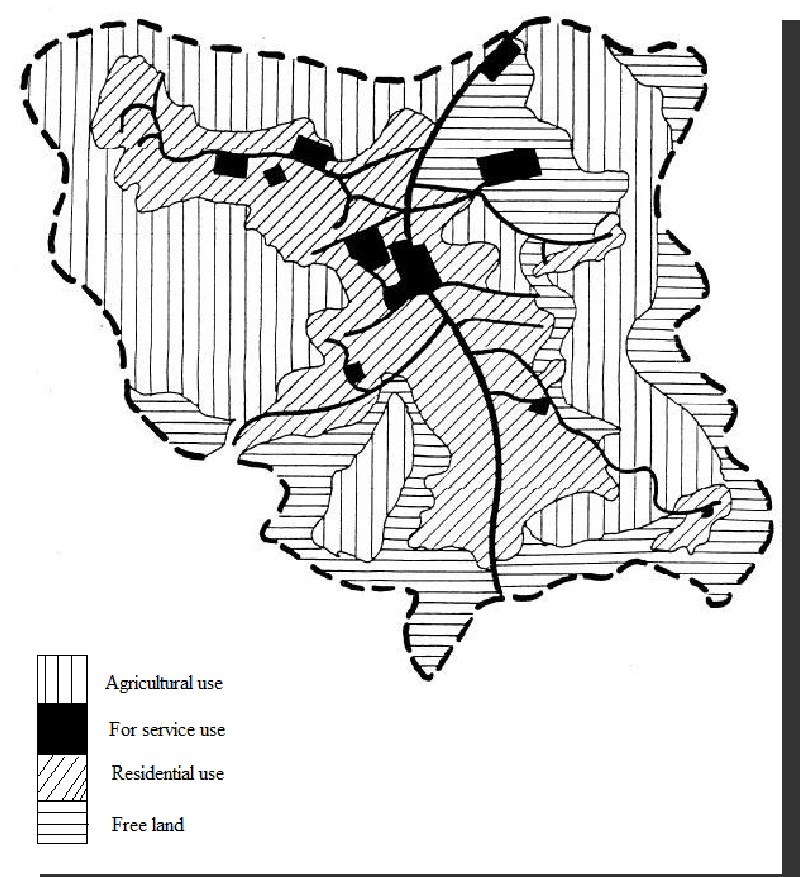

Fig. 2. Land-use plan of village Al-Obaidiyah 
The most important aim of the study is to define to what extent the Saudi-Arabian rural developmental policies can be examined by analysing the map of rural land-use, which is considered to be one of the most significant elements of evaluating rural development.

The aim of the study is to analyse the village's map of land-use. The land-use customs of the villages in Saudi-Arabia are characterized by the dominance of agricultural use and limited use compared to the land-use samples of urban centres. As regards the examined village (the village of Al Obaidiyah) that can be found in Fig. 2 the basic function of the village was turned to a kind of service function by the agricultural function applied by the majority of the population there. The developmental plans of the Saudi-Arabian Kingdom are interested in providing service to each citizen and it has significant impact on the land-use patterns in this village [8].

Strengths and weaknesses of the village Al Obaidiyah are summarized in Table 2.

Strengths and weaknesses of the village Al Obaidiyah

\begin{tabular}{|l|l|}
\hline \multicolumn{1}{|c|}{ Strengths } & \multicolumn{1}{c|}{ Weaknesses } \\
\hline$+\begin{array}{l}\text { The increase of agricultural territories in the } \\
\text { village, where they grow cereals, wheat and } \\
\text { barley, and fruits such as apricot and peach. }\end{array}$ & $\begin{array}{l}\text { There are no public water-works in the } \\
\text { village and the population depend on the } \\
\text { under-surface wells to get water. }\end{array}$ \\
$\begin{array}{l}\text { The presence of several primary and } \\
\text { secondary schools. }\end{array}$ & $-\begin{array}{l}\text { The people in the village have an under- } \\
\text { surface waste-water system, which might } \\
\text { cause huge contamination. }\end{array}$ \\
$\begin{array}{l}\text { There are infrastructural services and good } \\
\text { public and private institutions in the village. }\end{array}$ & $-\begin{array}{l}\text { The open fields became landfill sites in the } \\
\text { There are many new wells drilled in the } \\
\text { village. }\end{array}$ \\
$\begin{array}{l}\text { There are commercial and industrial } \\
\text { activities (turnover) carried out in the village } \\
\text { due to the technical activities. }\end{array}$ & $\begin{array}{l}\text { environmental problems. } \\
\text { The significant decrease in the population } \\
\text { of the village, which is in close relation to } \\
\text { the issues of migrating to cities. }\end{array}$ \\
& $-\begin{array}{l}\text { The lack of employment opportunities of } \\
\text { rural population due to the inability of the } \\
\text { agricultural sector. }\end{array}$ \\
\hline
\end{tabular}

\section{Suggestions for developmental strategy}

From the above mentioned it can be clearly seen that by examining the village's map of land-use and the most important achievements it is for sure that urgent help is necessary to improve the situation of the village. To start the development process is indispensable in order to decrease migration of the population. The establishment of the proper economic activities is necessary in order to ensure the economically productive employment opportunities.

Further rural studies are needed for evaluation of the developmental processes and for understanding and measuring the real problems and needs of the village population in all the regions of the Kingdom of Saudi-Arabia.

\section{Conclusions and suggestions for the two case-studies}

1. In case of Egypt, it is necessary to do the regional planning before starting the rural development in order to prevent penetration of agricultural territories, which would finally obstruct the whole process of rural development.

2. In case of Saudi-Arabia, the division of land-use in the villages should be studied in the process of planning rural development.

\section{References}

[1] Alani M. J. Regional planning, Publisher: Dar Safa Aman, Amman, 2006.ISBN: 9957-24-248-2. pp. 35-45.

[2] Jama M. N. Rural Sociology and Rural Development, New University of Alexandria Publishing House, 2010. pp. 55-62. 
[3] Muharram I. Rural Development, Concept and Rules, Friedrich Naumann Foundation, Cairo. I. issue, 1994, $235 \mathrm{p}$.

[4] Hamdan M. R. Regional planning and rural development, Publisher: Al-Quds Open University, Jerusalem 2001,415 p.

[5] Issam El Din M., Egyptian Village between Reality and Future "The Case of the Villages of Assiut Governorate", King Saud University,Vol 19., I. issue, 2016, pp. 93-132.

[6] Map-of-Assiut-Governorate, [online] [17.03.2015]. Available at https://www.researchgate.net/ figure/Map-of-Assiut-Governorate-Egypt-Sites-in-red-color-represent-areas-ofmosquito_fig1_273144640

[7] Dixon Ch., Rural Development in the Third World,Taylor \& Francis Ltd London, 2016, pp. 60-90.

[8] Al-Kahtani M. Sh, Changes in Rural Land use of the Kingdom of Saudi Arabia: The Case of AlAbidiah Illage in Asir Region. King Khalid University, Abha, 2004, pp. 3-44. 